\title{
9
}

\section{The Trusteeship Paradigm in the Social Sciences}

Moral Agency as an Islamic Ethical Turn

\author{
Mohamed Amine Brahimi
}

\section{Introduction}

Taha Abderrahmane (b. 1944) is a unique voice in the Muslim intellectual world. Professor Emeritus of philosophy at the University of Rabat (Morocco), Abderrahmane started his career as a scholar of logic and language. He afterwards gained prominence thanks to an innovative project which aims to develop a modern ethical theory in line with Islamic values. The period following the attacks of September 11, 2001, sees Abderrahmane publish a series of books with the goal of offering an Islamic response to this new political situation ('Abd alRahmmān 2003; 2005; 2006). This involves a critique of Western universalism in order to produce an alternative vision of modernity. In this project, the i'timāniyya paradigm, translated as the trusteeship paradigm (Hashas 2015) plays an important role. This new lexical and intellectual model finds as a starting point a vision of "reason" as cognitive activity producing meaning ('Abd al-Raḥmān 1998).

In this chapter, I try to explore the trusteeship paradigm following the engagement of Abderrahmane with modern philosophy and social sciences. How can we establish a dialogue between the philosophical trusteeship paradigm, rooted in the Islamic tradition, and other contemporary advances in moral theories and theories of religion? To approach this question, two major figures, representatives of the "ethical turn" - by which is meant a convergence from various horizons and traditions of human and social sciences focused on the moral subjects and their subjectivity (Fassin 2014) — will be examined comparatively; i.e., the communitarian philosopher Alasdair MacIntyre (b. 1929), and the postcolonial anthropologist Talal Asad (b. 1932). MacIntyre understands "reason" within practice and in a teleological structure; it will be shown how Abderrahmane's critique of Western modernity can interact with this type of philosophical reading. As Asad he proposes to define Islam as a "discursive tradition" and to study together religious ethical practices and the discourses that underpin them. It will also be shown how close the trusteeship paradigm is to this definition. Otherwise said, it will also be shown how these theoretical 
advances in the social sciences in general, and in the study of religion and morality in particular, have answers, or at least theoretical coverage, in some modern ethical theory rooted in the Islamic tradition, as the trusteeship paradigm and its comprehensive concepts show.

In the first part of this chapter, a summary of the published literature in the social sciences regarding the issue of morality is outlined. This will allow us to reframe the theoretical context that characterizes the ethical turn. In the second part, the trusteeship paradigm according to Abderrahmane is presented. This allows us to outline some of the main themes of this ethical theory. Finally, a parallel thread of thought between Abderrahmane, MacIntyre and Asad will be explored. The purpose of this comparison is to contextualize Abderrahmane within the ethical turn scholarship and see how the trusteeship paradigm can be combined with other socio-anthropological and moral approaches on religious belief in modern societies.

For a long time ignored, the issue of morality has in recent years generated significant interest in the field of social sciences. Influenced by the Durkheimian approach, many researchers have interpreted values as being the reflection of a certain type of social organization. ${ }^{1}$ Hence, every judgment of an ethical nature is understood to be an act of participation in the moral structure of society. This functionalism plays part in establishing morals as having a stake in a system of norms which sociologists acknowledge and decode. Starting in the 1990s, a significant body of research, mainly in the field of anthropology, has aimed to challenge this worldview (Laidlaw 2014).

The renewed interest in ethics in the scholarship of the social sciences stems from developments in moral philosophy. It draws on approaches that may be qualified as the "aretaic turn" or "virtue ethics." Working against the currents of modern philosophy, its representatives make the issue of virtues central to their analyses. Following her article "Modern Moral Philosophy", Elizabeth Anscombe (1919-2001) has become a precursor to this kind of approach (Anscombe 1958). This British philosopher takes a critical view on the idea of an autonomous moral subject. According to her, justice implies an instituted

1 It is important to note that Durkheim tried to develop an approach towards morality that opposes Kantian and utilitarian worldviews. It has, however, gained little attraction among Durkheim's followers (see Müller 1986). 
higher social power tasked with inciting people to obey laws. This unconditional moral duty remains coherent only in the framework of a theological conception of morals. Anscombe argues in favor of abandoning the concept of Kant's categorical imperative. As a substitute, she relies on the clarification of a fundamental concept, virtue, as a preliminary definition, before all discussion of morals. Anscombe makes practice the focus of her concern: virtue allows determining the deeds of a person all the while being continuously redefined by human activity. These a priori notions return to the issue of morality, to its collective dimension; the good life is then acquired through the practice of virtue for its own sake, but also through interactions with virtuous persons.

This notion of virtue as a central theme of the study of ethics has spawned a series of philosophical investigations. For example, Philippa Foot (1920-2010) has attempted to develop a conception of moral action in opposition to individual views on ethics (Foot 1978). For her, subjectivism makes morality a function of personal prerogatives: a specific understanding of facts and feelings pushes one to evaluate our actions as being good or evil. To counter this idea, Foot identifies virtues as being the result of a practical rationality, reacting to a given context which motivates good deeds. From the same perspective, Bernard Williams (1929-2003) refutes the ideals of contemporary reflections on morality (i.e., rationality, impartiality, generality) (Williams 1985). He criticizes the Kantian claim that people should adopt a neutral and objective point of view on their behaviors. According to Williams, all moral obligation arises from collective deliberation. This consensus results in a practical conclusion, and always applies to an actor with respect to a given action. A major work that focuses on virtue ethics is After Virtue by Alasdair MacIntyre (MacIntyre, 1984). This author draws out an analysis of the current state of moral discourse in which he identifies a profound irrationality. Basing his reflections on Aristotelian philosophy, he demonstrates that a system centered on virtues allows for a more coherent view of moral action.

The aretaic turn has influenced a set of anthropological studies on the topics of virtue and freedom, which share a meticulous analysis of moral subjects and their subjectivity. The goal of these studies is to counter the abstract definition of a collective by means of a set of norms, as it is the case in functionalist approaches. They are interested in the processes whereby these individuals construct the experience of norms in their day-to-day practice. The first anthropologist to articulate this theoretical renewal is Talal Asad. His genealogy of Christianity (Asad 1993) insists on corporal discipline and the role of asceticism in the construction of Catholic actors. From a similar viewpoint, Saba Mahmood and Charles Hirschkind direct their interests towards the religious 
renaissance in contemporary Egypt. Mahmood (2011) studies five mosques in Cairo which were exclusively attended by women in 1995 . She is interested in the practices they engage in with the aim of cultivating piety in their daily life. It is through this process of subjectivation that they attain a pious self. As for Hirschkind (2009), he centers his reflections on the role of audio cassette recordings of sermons in a popular neighborhood of Cairo. This author describes the effects these instruments have on the preservation of an ethical living tradition in Islam, within a framework of modern technologies and politics. In both cases, the ethical referent shares a continuity with the daily practices of a religious lifestyle. Whereas a Eurocentric approach to religion sees faith as the true locus of religiosity, these studies switch focus to rituals. Contrary to the liberal conceptions, they put in opposition belief and piety so as to attain a more precise description of types of religiosity. The scope of ethics is then redefined as a technology of the body where practice substitute belief.

This brief overview contextualizes the ethical turn, be it in the philosophic or ethnographic field. These approaches thus aim to redefine the moral subject in terms of practice, context and collectivity. It is, as a result, convenient to examine it with reference to the philosophy of Taha Abderrahmane.

\section{The Trusteeship Paradigm according to Taha Abderrahmane}

The Paradigm of Trusteeship must be understood within a broad framework of applied ethics. Indeed, since 200o, Abderrahmane's attention has become more and more directed towards moral issues (Hashas 2015, 7), the goal being to enable Muslims to respond to the challenges of the modern world ('Abd alRaḥmān 2002). Abderrahmane draws on Islamic ethics to construct a criticism of values imported from the West under the banner of universalism. This source allows him to lay down the path following which the Muslim world can renew itself. It is a matter of understanding the spirit of Islam (its moral foundation) as a reaction to the cultural hegemony of the Western world. This project takes shape symmetrically: one must have a critical view of the spirit of modernity to construct the Muslim specificity.

Abderrahmane (2006, 24-26) breaks Western modernity down into three principles: majority, criticism and universality. The principle of majority is the transition from the minor status into the major status, i.e. freedom from guardianship, in the Kantian sense. This principle underlies two essential elements: autonomy and creativity. The principle of criticism is the transition from a condition of belief to a condition of doubt. This critical outlook points 
to the impossibility of a metaphysical understanding of God, and is mainly based on rationalization and differentiation. The principle of universality is the transition whereby modernity switches from being specifically Western to being universal. It rests on two pillars: the extendibility of moral principles into all aspects of social, political and individual life, and a generalization thereof across all other non-Western societies, without regard for cultural and historical differences.

As such, the spirit of modernity can be defined as "major, critical and universal" ('Abd al-Raḥmān 2006, 29). Based on these premises, Abderrahmane sets forth the preliminary conditions for the foundation of an Islamic modernity. First of all, it is necessary to avoid the negative effects of the West's application of the spirit of modernity. Second, one must consider modernity as being a transformation that is internal to Islamic societies; and, third, it is essential to perceive modernity as a creative process that does not limit itself to imitations of pre-established models ('Abd al-Raḥmān 2006, 35).

The analytical foundation necessary to establish this alternative modernity is found in the trusteeship paradigm, which is based on three cardinal principles: (1) shahāda, (2) amāna, and (3) tazkiya (i.e., testimony, trust, and selfpurification, respectively). First, the shahāda principle (testimony or profession of faith) "allows the individual to reconnect with his or her original nature" ('Abd al-Rahmān 2014, 14-19). Contrary to the conception of a completely autonomous subject, the principle of shahāda implies the testimony of others. The trusteeship paradigm thus rests on the behavior or a manner of thinkingan attitude-which tends to focus on others through one's own actions. The shahāda in its multiple forms presupposes an engagement in shared interaction: the shahāda in facing God, the shahäda in facing the Prophet, the shahāda in facing close relatives, the shahāda in facing distant strangers ('Abd al-Raḥmān 2014, 14). As to the amāna principle (trust, or deposit), it incites to free the human being from the spirit of appropriation. This principle makes its actor responsible regarding the impact of their actions. All that exists in the world represents an amāna (trust) to the human being. This principle ties reason to a duty of responsibility towards human, animate and inanimate beings. The harmony produced by this responsibility allows individuals to preserve their environment from that which is harmful to existence ('Abd al-Rahmān 2014, 15). As to the tazkiya principle (self-purification or selfdiscipline), it incites the realization of moral values and spirituality of the community in the long term. The tazkiya calls upon the individual to materialize the moral values and the spirituality required to satisfy the Almighty Creator. This both personal and collective education ensures the personal development of individuals together with society as a whole. The tazkiya determines the moral 
norms and provides people with the tools to enact them. Through its mediation, the collective perpetuates its moral and spiritual potential, thanks to the mutual interaction of individuals ('Abd al-Raḥmān 2014, 16).

Abderrahmane uses the principles of trusteeship as prescriptive guides to his work; they allow him to offer an alternative to the spirit of modernity. These principles lead him to elaborate a project of renovation which sees the human being as the driving force of change and development in society. They reject all separation of ethics and religion, with the aim to participate in a contextual universality. The latter consists in a commonly shared thought process which respects the specific traits of every culture ('Abd al-Rahmān 2006, 66). In what follows, I will explore the ways in which the principles of the trusteeship interact with virtue ethics light of thought. The analysis below will rest upon two important contributors to this movement: Alasdair MacIntyre and Talal Asad.

Taha Abderrahmane and Alasdair MacIntyre: The Trusteeship Paradigm as a Critique of Modernity

Abderrahmane and MacIntyre join hands in a critique of modernity. The book After Virtue (1984) has confirmed MacIntyre as a major figurehead of moral philosophy. He analyses the dissolution of practical reason under the influence of liberal atomism, and argues for the reconstruction of a communitarian spirit. MacIntyre draws his inspiration from a critique of atomism put forth by Ludwig Wittgenstein in his Philosophical Investigations (1976). Based on Wittgenstein's analysis, he puts much effort to demonstrate that, in order to define freedom, one cannot follow an empiricist or mechanical description of action. The absence of constraints only takes shape through finalities, practices and a conception of the world. However, modern philosophers place moral issues into the private sphere, a space in which everyone can do as they please without facing exterior intervention (MacIntyre 1984, 52). Indeed, the modern project of the Enlightenment was to endow individuals with a fundamental freedom by establishing the rational norms of good behavior as the autonomous subject. Criticizing this conception, this philosopher holds that freedom does not come about through an absence of exterior obstacles, but through the absence of interior obstacles (MacIntyre 1988, 355). Freedom must include a juncture where a conception of good is instituted, allowing one to withdraw these obstacles. These morals are profoundly anchored in practice:it represents places of expression and of deployment of its norms (MacIntyre 1984, 177). In 
this sense, the essence of practice rests upon internal goodness that shapes the foundation of its coherence, and gives meaning to the rules one must follow. These virtues allow one to achieve excellence in the performance of an activity, and they come before the institution of collective morals (MacIntyre 1984, 182 ).

As previously discussed, Abderrahmane outlines three principles of modernity (majority, criticism, universality), the goal being the establishment of an Islamic modernity based on the trusteeship paradigm. It is in his criticism of the principles of Western modernity that Abderrahmane shares MacIntyre's viewpoint.

With a basis in the specificities of Islam, Abderrahmane readdresses the concept of majority. For him, the cultural autonomy of Muslim countries results from their desire not to imitate the West ('Abd al-Raḥmān 2006, 37). Thus, for him, freedom does not rely on the isolation of the religious aspect of life since it represents the moral pathway of Islam. As in MacIntyre, Abderrahmane's view is a vision of positive freedom that results in the possibility of performing an action. Freedom is thus immediately put to use in the capacity of actors to accomplish an ideal that surpasses them. For Abderrahmane, this conception is reflected in the inversion undergone by the question of autonomy. The main force that thwarts the Muslim world's flourishment comes down not to Islamic norms, but to Western imperialism, i.e. Western guardianship.

As to the principle of criticism, Abderrahmane $(2006,43)$ perceives critical thinking as being West-centric. Its interpretation remaining one-dimensional, it keeps western minds from addressing the true concerns of Muslims. Indeed, moral values cannot be understood as a function of doubt, but rather of faith and of good conduct. This spiritualist path echoes MacIntyre's line of thought. For MacIntyre, individual autonomy does not rely only on the exercise of critical reason, but also on ideals that allow citizens to achieve their comprehensive maturity. To do so involves maintaining an inner voice that all humans are endowed with. For MacIntyre, this moral sense depends on a substantial context and can only affirm itself through criticism.

As regards the principle of universality, Abderrahmane rejects the separation of modernity and turäth (tradition). For him, religion is not to be relegated as an incoherent line of thinking; rather, it reflects a particular rationality. Sacredness is indispensable to human life and can rescue humans throughout their journey on Earth ('Abd al-Rahmmān 2006, 48). MacIntyre is likewise critical of the separation of values and actors. If restricted to a vision of the subject inde- 
pendent of all philosophical traditions, we lose the foundations of a practical rationality. Truth only becomes apparent in the framework of the development of existing intellectual traditions.

From the parallels between MacIntyre and Abderrahmane, one shared view comes to the fore: the impossibility of interpreting moral issues through a modern framework. This observation comes from modern moral philosophy's denial of social underpinnings and practical rationality, as well as its rejection of all external moral authority. Whether deontological or utilitarian, this type of philosophy assumes the existence of autonomous subjects relying only on their individual conscience for guidance. For their part, the two philosophers understand knowledge and truth as being the results of a collective interaction in the framework of a philosophical tradition. They counter modernity founded on a completely autonomous critical subject with a social life that is not a sum of individuals. For them, the human being is driven by a natural desire to live in society; morals thus acquire meaning from this ontological presupposition. The goal of the trusteeship paradigm is to regain the principles which may restore the natural order to man; it therefore transits through a critique of the limits of Western morality.

Taha Abderrahmane and Talal Asad: The Trusteeship Paradigm as the Practical Dimension of the Islamic Tradition

The juncture point between Asad and Abderrahmane take place in their relation to tradition. For Asad, Islam does not have the properties of an individual belief, but rather of a disposition to be and to act in conformity with the Divine Will. Faith ( $\bar{i} m \bar{a} n)$ is a virtue; it is cultivated by repeating acts of devotion (Asad 2003, 90). Asad defines Islam as a "discursive tradition", i.e. an educational process for the faithful, which takes place in a specific constellation of meanings (Asad [1986] 2009). The tradition is kept alive by practices, and it allows the faithful to act and to think as part of a community. Rituals build moral character, the goal being to shape and to exercise certain forms of subjectivity.

For Asad, Islamic jurisprudence ( figh) must be understood within this framework. It cannot be dissociated from the moral duty (to do good) and from social issues (the call upon the believer to do good) (Asad 2003, 243). Islamic morals are then, so to speak, interlaced with social relations that construct a religious community. The Sharia thus depends on the moral ability to judge behavior as being good (both for oneself and for others). This virtue is acquired through a learning process that starts in childhood and lasts through all adult- 
hood (Asad 2003, 248). The ability to make judgments on given situations often takes a collective shape: it assumes the intervention of authorities, of close ones, or of friends.

Abderrahmane likewise views religious experience as a synthesis of the law and moral duty. He interprets religious practices as having two phases: an external or formal expression, which takes the shape of legalism, and an expression that manifests itself through the internal subjectivity of the believer ('Abd al-Raḥmān 2002). The religious act is therefore a response to a temporal reality, figh, and a spiritual preoccupation, the goal being the production of an action in accordance with the Divine Will. Within this framework, religion is not exclusively experienced in terms of the private sphere; it globally merges into all aspects of human life. Islam transcends mere judicial matters: it enjoys an ontological role that emerges from the good deeds that human beings/believers accomplish (Abderrahmane, 200o).

For Abderrahmane, the three pillars of the trusteeship paradigm (shahäda, amāna, tazkiya) ('Abd al-Rahmmān 2014, 14-19) allow the faithful to follow the Sharia as a moral path. Describing this view of Islam, Abderrahmane's work runs parallel to that of Asad. For the latter, the concept of shari'a must be understood as a body of recommendations and reflections on the moral conduct of Muslims that is appropriate according to different religious schools of thought. In the same manner, Abderrahmane maintains that the practice of good is built around a rationality that materializes morals by drawing on a source of religious heritage. The Sharia is therefore represented as a way of being and of acting within one's environment.

The shahāda principle ('Abd al-Rahmmān 2014, 14) corresponds to the common beliefs that are shared by the faithful. It represents a common relation to sources of knowledge, and therefore refers Muslims to the different divine prescriptions that they are tasked with interpreting. The shahāda is a preliminary step in the historical construction of the moral path, and constitutes the basis of the belief system within divine and prophetic teachings. Asad endorses the same premise when considering the Qur'an and the Sunna as foundational pillars of the tradition. He also insists on the historicity of the concepts, practices and debates that underscore this tradition (Asad [1986] 2009, 14).

As to the amāna principle, it represents for Abderrahmane a moral dimension of Islam as well as the duties that result in just practices ('Abd al-Raḥmān 2014, 14). Thus, not only are human beings responsible for their own little worlds and concerns alone, but they also are responsible for the vast world surrounding them. In a similar manner, Asad insists on the importance of a proper model to define practice in Islam. This model keeps the tradition alive 
in Muslim people's everyday life, showing it to be the vessel of morals that Muslims must respect. In this way, the two scholars agree on a conception of morality that is capable of constructing the behavior of the faithful in accordance with their environment.

As to the tazkiya principle, it represents the act of recommendations: it includes all forms of moral correction, treatment, and prevention from evil, its purpose being the development of moral tendencies within the community of believers ('Abd al-Rahmmān 2014, 16). Asad likens tazkiya to the concept of orthodoxy; for him, it is the domain within which Muslims adjust, exclude, or replace certain practices. In both cases, a council is constructed in accordance with tradition, in the development of a general framework of interaction. Each Muslim thus has the duty to call others to do good deeds, as well as the power to condemn evil actions.

From the comparison of Asad and Abderrahmane, it becomes apparent that Islam cannot be analyzed as a mere belief system. It operates with a strong moral and practical dimension, inside which sources of authority play an important role. Thus, within their own religious space, Muslims are not simply constrained to performing good acts, they are also responsible for carrying about their environment.

The matter is for all Islam's adherents to rectify their behavior as well as that of their peers by relying on normative sources of Islam: the Quran, the Hadith, Consensus $\left(\ddot{j} m \bar{a}^{c}\right)$, and analogy (qiy $\left.\bar{a} s\right)$. The Sharia then becomes significant as a system of morals that acquire meaning in prescribing well, as well as in prohibiting evil (al-amr bi-l-ma'rüf wa-l-nahy 'an al-munkar). This duty, which can be an individual duty ( fard 'ayn) or a collective one ( fard kifäya), depending on the interpretation, is then accomplished through either a competent authority if collective or a moral agent if individuals.

\section{5}

\section{Virtue Ethics and the Trusteeship Paradigm: A New Approach in the Social Sciences?}

The parallelism shown between virtue ethics and the trusteeship paradigm demonstrates agreeing visions on the subject. It refocuses our representation of the human being around moral issues. Thus, we deal with Homo Ethicus, endowed with a duty that transcends their mere personal interests. The comparison of Abderrahmane's writing with those of MacIntyre reveals many points of intersection. Indeed, the two philosophers identify the limits of modern Western philosophy in addressing moral issues. Asad and Abderrahmane approach Islam in similar manners, by stressing the importance of tradition 
in understanding the religious practice of Muslims. This theoretical intersection can be a significant contribution to research in the social sciences. It pushes scholars to question multiple analytical assumptions. To conclude, I will outline three theoretical directions that demonstrate the contribution of Abderrahmane in the theoretical comprehension of Islamic practices and subjectivity: (1) the critique of Cartesian materialism, (2) the rejection of individualism and holism as sole alternatives, and (3) the consideration of the agency.

First, virtue ethics and the trusteeship paradigm are opposed to Cartesian materialism (Descartes 1936 [1637]), specifically in the way they treat the relationship between mind and body. Descartes identifies the existence of two types of substance: the mind or soul (res cogitans) and the body (res extensa). Further, in his view, each of these two substances interacts with the other, and mental states have a causal effectiveness over physical states. Thence comes to an understanding of humans as chiefly driven by reason. As concerns virtue ethics, its proponents give primacy to action rather than to reason. All forms of cooperative activity socially produce norms of excellence as well as a conception of finalities (MacIntyre 1984, 182). Abderrahmane offers a critique of the Cartesian thinking subject. Facing the Cartesian maxim "I think, therefore I am", he puts forth the "shahäda principle", whereby the accomplishments of a human being are testified by others. As a result, they must engage in a moral behavior. The constitution of a subject acquires meaning in judgment and in practice, rather than in speculation (alone).

Second, virtue ethics and the trusteeship paradigm also offer an alternative path between holism and individualism. The history of social sciences is often presented as an opposition of these two traditions: the first conceives of social phenomena as having their own essence, independent of people's consciousness and willpower (holism); on the contrary, the second states that social phenomena result from the layering and combination of the conducts of rational participants, conceived of as logical "atoms" of the analysis (individualism) (Kincaid 1993). The study of Islam conducted by Asad shows in which manner discipline generates a pious self by cultivating virtue through specific practices. However, to be considered Islamic, all practice must gain social recognition. The individual is inscribed within a collective tradition which also structures their social conduct (Asad [1986] 2009). Elsewhere, Abderrahmane questions the primacy of the individual. In laying out the principle of tazkiya, he places the moral education of an individual at the core of society. $\mathrm{He}$ rejects the mutual exclusion of the individual versus society, or vice versa. The moral efforts put forth by individuals contribute to guaranteeing their selfdevelopment. In turn, the collectivity exploits their moral potential by placing 
them in interaction with others. Far from splitting holism and individualism, the moral-minded approach leaves space for individual subjectivity all while accounting for collective socialization.

Third, the trusteeship paradigm reinstitutes the significance of agency in the understanding of human behavior; therefore, it establishes itself as a critique of Kantian morals. For Kant, the will of humans is subject exclusively to moral law, which must be obeyed for the sake of itself and is enforced on us in the shape of the categorical imperative (Kant 1993). It corresponds to acts that must be enacted unconditionally, and only acts whose maxims correspond to its principles are seen as moral. Based on this moral law, Kant places the ability to judge at the center of his conception of an autonomous subject (Kim 2015, 40). By contrast, the trusteeship paradigm centers its attention on agency, which represents the capacity to act unto the world, the objects or with the other beings, and to transform or influence them (Barker 2007, 448). In the trusteeship paradigm, all what exists in the world represents an amāna (a trust, a deposit) for human beings, for which they are responsible before God. Therefore, they have a duty which transcends their mere judgment, as it also includes the ends of their actions. Similarly, by subjecting themselves to norms and rituals, Asad means to show how religious actors form a subject capable of acting, without becoming autonomous in the Kantian sense (Asad [1986] 2009). MacIntyre likewise criticizes moral consequentialism: in his view, all ethical consideration should not be focused on finalities rather than on deeds (MacIntyre 1984). These three incursions offer tools to articulate the trusteeship paradigm in relation to human and social sciences. The concepts of Abderrahmane are in dialogue with various contemporary social theories, particularly around the issue of virtue ethics. This said, not only should the concepts of Taha Abderrahmane be studied, but the intellectual process of his approach should be applied to renew our outlook on Muslim societies and better understand the ins and outs of human action.

\section{References}

'Abd al-Raḥmān, Țāha. 1987. Fì Ușül al-Hiwār wa-Tajdìd Ilm al-Kalām [On the Sources of Dialogue and Renovation of Islamic Theology]. Casablanca and Beirut: al-Markaz al-Thaqāfī al-Arabī.

'Abd al-Rahmmān, Țāha. 1989. Al-'Amal al-Dīnì wa-Tajdìd al-'Aql [Religious Practice and the Renewal of Reason]. Casablanca and Beirut: al-Markaz al-Thaqāfì al-'Arabī.

'Abd al-Raḥmān, Ṭāha. 1994. Tajdīd al-Manhajfi Taqwīm al-Turāth [Renewing the Method of Assessing the Tradition]. Casablanca and Beirut: al-Markaz al-Thaqāfì al'Arabī. 
'Abd al-Raḥmān, Țāha. 1995. Fiqh al-Falsafa 1: al-Falsafa wa-l-Tarjama [The Essence of Philosophy 1: Philosophy and Translation]. Casablanca and Beirut: al-Markaz alThaqāfì al-'Arabī.

'Abd al-Raḥmān, Țāha. 200o. Su'āl al-Akhlāq: Musāhama fíal-Naqd al-Akhlāqī lil-Hadātha al-Gharbiyya [The Question of Ethics: a Contribution to Ethical Criticism of Western Modernity]. Casablanca and Beirut: al-Markaz al-Thaqāfī al-'Arabī.

'Abd al-Raḥmān, Ṭāha. 2002. Al-Haqq al-'Arabìfì al-Ikhtilāf al-Falsafı̀ [The Arab Right to Philosophical Difference]. Casablanca and Beirut: al-Markaz al-Thaqāfî al-'Arabī. 'Abd al-Raḥmān, Ṭāha. 20o3. Hiwāāāt min Ajl al-Mustaqbal [Dialogues for the Future]. Beirut: Dār al-Hādī.

Abderrahmane, Taha. 2004. "Essence of Modernity and Right to Creativity." ISESCO Journal of Islam Today 21: 1-42. Retrieved on 31 August 2011, from www.isesco.org .ma/english/publications/islamtoday/21

'Abd al-Raḥmān, Ṭāha. 2005. Al-Haqq al-Islāmī fì al-Ikhtilāf al-Fikrī [The Islamic Right to Intellectual Difference]. Casablanca and Beirut: al-Markaz al-Thaqāfī al-'Arabī.

'Abd al-Raḥmān, Țāha. 2006. Ruḥ al-Hadātha: Naḥwa al-Ta'sīs li-Hadātha Islāmiyya [The Spirit of Modernity: An Introduction to Founding an Islamic Modernity]. Casablanca and Beirut: al-Markaz al-Thaqāfì al-'Arabī.

'Abd al-Raḥmān, Ṭāha. 2007. Al-Hadātha wa-l-Muqāwama [Modernity and Resistance]. Beirut: al-Mac̄rif al-Ḥikamiyya, Ma'had al-Dirāsāt al-Dīniyya wa-l-Falsafiyya.

Abderrahmane, Taha. 2008. "Renewing Religious Thought in Islam: Prerequisites and Impediments." IS Es co Journal of Islam Today 25: 1-13. Retrieved on 25 August 2011, from: www.isesco.org.ma/english/publications/islamtoday/25/P7.php.

Abderrahmane, Taha. 2008. "A Global Ethic: Its Scope and Limits." Abu Dhabi Tahab Paper Series, 1: 1-19.

Abderrahmane, Taha. 20o9. "Pluralism of Values: Its Scope and Limitations." Trans. Karim Crow. Journal of Islamic Civilizational Renewal 1 (1): 74-98.

Abderrahmane, Taha. 2010. "Language Matters: A Dialogue on Language and Logic." Tabah Foundation of Abu Dhabi Paper Series 1: 1-34.

'Abd al-Raḥmān, Țāha. 2012. Su'āl al-'Amal: Baḥth 'an al-Ușūl al-'Amaliyya lil-Fikr wa-lIlm [The Question of Doing: A Search for Practical Origins in Thought and Science]. Casablanca and Beirut: al-Markaz al-Thaqāfì al-'Arabī.

'Abd al-Raḥmān, Țāha. 2013. Al-Hiwār Ufuqan lil-Fikr [Dialogue as a Space for Thought]. Beirut: al-Shabaka al-'Arabiyya lil-Abḥāth wa-l-Nashr.

'Abd al-Raḥmān, Țāha. 2014. Bu's al-Dahrāniyya: al-Naqd al-I'timānī li-Faṣl al-Akhlāq 'an al-Din [The Misery of Secularism: Trusteeship Critique of the Separation of Ethics from Religion]. Beirut: al-Shabaka al-'Arabiyya lil-Abhāth wa-l-Nashr.

Anscombe, G.E.M. 1958. "Modern Moral Philosophy." Philosophy 33 (124): 1-19.

Asad, Talal. 1993. Genealogies of Religion: Discipline and Reasons of Power in Christianity and Islam. Baltimore: Johns Hopkins University Press. 
Asad, Talal. 2003. Formations of the Secular: Christianity, Islam, Modernity. Palo Alto: Stanford University Press.

Asad, Talal. [1986] 2009. "The Idea of an Anthropology of Islam." Qui Parle 17 (2): 1-30. Barker, Chris. 2007. Cultural Studies: Theory and Practice. London: SAG E.

Descartes, René. 1936. Discours de la méthode: Méditations métaphysiques; Traité des passions. Paris, New York: Édition Lutetia.

Fassin, Didier. 2014. "The Ethical Turn in Anthropology: Promises and Uncertainties," HAU: Journal of Ethnographic Theory 4 (1): 429-435. https://doi.org/10.14318/hau4.1 .025 .

Foot, Philippa. 1978. Virtues and Vices and Other Essays in Moral Philosophy. Berkeley: University of California Press.

Hashas, Mohammed. 2015. “Taha Abderrahmane's Trusteeship Paradigm.” Oriente Moderno 95 (1-2): 67-105. https://doi.org/10.1163/22138617-12340077.

Hirschkind, Charles. 2009. The Ethical Soundscape: Cassette Sermons and Islamic Counterpublics. New York: Columbia University Press.

Kant, Immanuel, and James Wesley Ellington. 1993. Grounding for the Metaphysics of Morals: With On a Supposed Right to Lie Because of Philanthropic Concerns. Third Edition. Indianapolis: Hackett Publishing Company.

Kim, Halla. 2015. Kant and the Foundations of Morality. New York: Lexington Books.

Kincaid, Harold. 1993. "The Empirical Nature of the Individualism-Holism Dispute," Synthese 97 (2): 229-247.

Laidlaw, James. 2014. The Subject of Virtue: An Anthropology of Ethics and Freedom. Cambridge: Cambridge University Press.

MacIntyre, Alasdair C. 1984. After Virtue a Study in Moral Theory. 2nd ed. Notre Dame, IN: University of Notre Dame Press.

MacIntyre, Alasdair C. 1988. Whose Justice? Which Rationality? Notre Dame, IN: University of Notre Dame Press.

Mahmood, Saba. 2011. Politics of Piety: The Islamic Revival and the Feminist Subject. Princeton: Princeton University Press.

Müller, Hans-Peter. 1986. "Société, morale et individualisme. La théorie morale d'Emile Durkheim.” In Hans Bertram (ed). Gesellschaftlicher Zwang und moralische Autonomie. Frankfurt am Main: Suhrkamp: 71-105.

Williams, Bernard. 1985. Ethics and the Limits of Philosophy. Cambridge: Harvard University Press.

Wittgenstein, Ludwig. 1976. Philosophical Investigations. Oxford: Blackwell. 